\title{
INTERNA KONTROLA KAO MJERA PREVENCIJE PREVARA U FINANSIJSKOM IZVJEŠTAVANJU
}

\section{Nataša Simeunović ${ }^{1}$, Goranka Knežević}

\author{
${ }^{1}$ Univerzitet Sinergija, \\ Bijeljina, Bosna i Hercegovina \\ ¿Univerzitet Singidunum, \\ Beograd, Srbija
}

\begin{abstract}
Apstrakt:
U cilju postizanja kvalitetnog korporativnog upravljanja, a samim tim i upravljanja rizikom kompanije, neophodno je dobro razumijevanje sistema internih kontrola i načina na koji one funkcionišu u praksi. Razlog tome leži u činjenici da način upravljanja rizicima zavisi od učinkovitosti sistema internih kontrola, odnosno od sposobnosti organizacije da spozna rizike, koji utiču ili bi mogli uticati na njeno poslovanje, zavisi i kvalitet korporativnog upravljanja.

Interna računovodstvena kontrola predstavlja sveukupan i kompleksan sistem finansijskih kontrola, koje su prije svega formalne, suštinske i usmjerene ka obezbjeđivanju razumnog uvjeravanja u efikasnost i uspješnost poslovanja, u njegovu usklađenosti sa zakonima i propisima. Interna računovodstvena kontrola pruža zaštitu sredstava od neovlašćene upotrebe i otuđenja, omogućava pravilno i uredno vođenje knjigovodstvenih evidencija, kako bi se dobile pouzdane finansijske informacije koje se koriste za pružanje poslovnih informacija i donošenje odluka. U cilju efikasnog i efektivnog upravljanja rizikom u organizaciji, nadležnosti po pitanju rizika i kontrole se dijele i dodjeljuju različitim odjeljenjima i sektorima u organizaciji, a njihovo pažljivo i koordinisano sprovođenje obezbjeđuje da proces upravljanja rizikom i kontrole funkcionišu na željeni način. U ovom rada ćemo se bliže osvrnuti na internu kontrolu kao jedno od značajnih sredstava organizacije, tzv. prvu liniju odbrane u borbi protiv prevarnih radnji u finansijskom izvještavanju, te stepen njihove implementacije i efikasnosti na primjeru privrede $\mathrm{BiH}$.
\end{abstract}

Ključne reči:

interna kontrola, prevencija prevara, upravljanje rizikom.

\section{UVOD}

Organizacione kontrole predstavljaju ključan element borbe protiv prevara, no nije ih nemoguće zaobići naročito u slučajevima kada do prevare dolazi po dogovoru. Iz tih razloga, svaka organizacija treba da uspostavi i energično sprovodi efikasne interne kontrole, kako bi se poslovanje obavljalo nesmetano. Ovi postupci služe da spriječe i otkriju greške (nenamjerne) i sve oblike (namjerne) neiskrenosti zaposlenih, klijenata, dobavljača, pa čak i samih menadžera. Nažalost, mnoga preduzeća nemaju dobre sisteme internih kontrola, ili neozbiljno sprovode svoje interne kontrole. Sistem interne kontrole predstavlja polaznu osnovu u koncipiranju cjelokupnog sistema internog nadzora. Posmatrajući s aspekta funkcionalnosti, sistem internog nadzora se može provoditi pomoću internih kontrola koje su implementirane u poslovne procese organizacije, te nadgledanjem njihovog funkcionisanja što se obezbjeđuje dodatnim, višim nivoom nadzora - internom revizijom.

Otkrivanje i istraživanje prevara nekad nije dovoljno već treba kreirati kvalitetan program prevencije prevarnih radnji koje bi spriječile njihov nastanak. Kao polaznu tačku, ovlašćeni istražitelj prevara preporučuje pristup koji uključuje sljedeće komponente (Durant, 2004):

- uspostavljanje odgovarajuće kulture,

- uspostavljanje politike dojavljivača (whistleblowers),

- identifikovanje rizika,

- uspostaviti efikasan sistem kontrola, 
- povećati nivo svijesti o mogućim rizicima,

- imati rezervni plan,

- zapošljavati prave ljude,

- tragati za transakcijama sumnjive prirode.

Kada kompanije planiraju zaposliti nove ljude, veoma je važno da rukovodioci budu svjesni da to moraju biti osobe od povjerenja, odnosno da će tim osobama povjeravati novac, povjerljive informacije kao i ugled kompanije. Kako bi riješile ovaj problem, kompanije bi morale uspostaviti procedure zapošljavanja koje bi se bavile i tim pitanjima. Razlog za to se može pronaći i u rezultatima MORI istraživanja (2001) prema kojem čak 30\% zaposlenih ne govori istinu kada se prijavljuje za posao, njih $18 \%$ smatra da se pri sastavljanju biografije mora pretjerivati, 34\% menadžera ne provjerava kandidatovu prošlost, a 36\% državnih organizacija smatra da gube značajne količine novca i vremena zbog neistinitih podataka u biografijama aplikanata.

\section{POJAM I FUNKCIONISANJE SISTEMA INTERNIH KONTROLA}

Jedna od osnovnih pretpostavki uspješnog poslovnog ambijenta jeste zdravo, kvalitetno finansijsko izvještavanje, a o njemu se može govoriti tek kada postoji sistem korporativnog upravljanja koji je funkcionalan i uravnotežen. Odlučujući element koji utiče na poboljšanje ekonomske efikasnosti i rasta, kao i na rast povjerenja investitora predstavlja korporativno upravljanje koje obuhvata skup odnosa između uprave kompanije, upravnog odbora, akcionara kao i drugih zainteresovanih strana. Ono je samo dio šireg ekonomskog konteksta u kojem firme posluju, a koji obuhvata, na primjer, makroekonomsku politiku i stepen konkurencije na tržištu proizvoda i faktora. Zakonsko, regulatorno i institucionalno okruženja su takođe faktori od kojih zavisi okvir korporativnog upravljanja. Pored pomenutih faktora, uticaj na reputaciju i dugoročni uspjeh kompanije, takođe, može imati poslovna etika, te zajednička svijest o interesima životne sredine i društvenim interesima zajednica u kojima kompanija posluje (OECD, 2004).

U cilju postizanja kvalitetnog korporativnog upravljanja, a samim tim i upravljanja rizikom kompanije, neophodno je dobro razumijevanje sistema internih kontrola i načina na koji on funkcioniše u praksi. Razlog tome leži u činjenici da način upravljanja rizicima zavisi od učinkovitosti sistema internih kontrola, odnosno da od sposobnosti organizacije da spozna rizike koji utiču ili bi mogli uticati na njeno poslovanje zavisi i kvalitet korporativnog upravljanja.

Postoji više definicija interne kontrole od kojih ćemo ovdje navesti neke od najznačajnijih.

Vjerovatno najpotpuniju definiciju interne kontrole je dao Committe of Sponsoring Organisations of the Treadway Commission - COSO. Prema COSO (1992), interne kontrole su definisane kao „proces, ustanovljen i sprovođen od strane upravnog odbora preduzeća, uprave i drugog osoblja s ciljem da obezbijedi razumno uvjeravanje vezano za postizanje ciljeva u sljedećim kategorijama: efikasnost i uspješnost poslovanja, pouzdanost finansijskog izvještavanja, usaglašenost sa postojećim zakonima i propisima i zaštita imovine od neovlašćenog prisvajanja, korišćenja ili otuđenja.“

Sistem interne kontrole je definisan Međunarodnim standardima revizije i to prvobitno u MRevS 400 (SRRS, 2004), prema kojem on obuhvata sve politike i postupke, odnosno interne kontrole koje je rukovodstvo pravnog lica prihvatilo, kako bi pomoglo da se ostvare ciljevi organizacije na način koji obezbeđuje odvijanje urednog i efikasnog poslovanja pravnog lica. To podrazumijeva da se pravno lice pridržava definisanih politika rukovodstva, da čuva integritet sredstava, da spriječava i otkriva kriminalne radnje i greške, čime se postiže tačnost i pouzdanost finansijskih evidencija i blagovremeno sastavljanje pouzdanih finansijskih informacija.

Prema Međunarodnom standardu revizije 315 - Prepoznavanje i procjenjivanje rizika značajnih pogrešnih prikazivanja tokom sticanja razumijevanja subjekta i njegovog okruženja (SRR-FBiH, 2013), koji je u decembru 2004. godine zamijenio MRevS 400, interna kontrola predstavlja „proces koji osmišljavaju, provode i održavaju oni koji su zaduženi za upravljanje, menadžment i ostalo osoblje, kako bi se osiguralo razumno uvjeravanje o postizanju ciljeva poslovnog subjekta u vezi s pouzdanim finansijskim izvještavanjem, efikasnim i uspješnim poslovanjem i usklađenošću s važećim zakonima i propisima. Pri čemu se pojam „kontrola” odnosi na sve aspekte bez obzira da li je riječ o jednoj ili više komponenata interne kontrole."

Pošto interna kontrola nije događaj ili okolnost već niz aktivnosti koje provjeravaju djelatnost pravnog lica i koje osmišljavaju i sprovode ljudi (upravni odbor, rukovodstvo i zaposleni u pravnom licu), od interne kontrole se može očekivati da pruži samo razumno, nikako apsolutno uvjeravanje rukovodstvu i upravnom odboru u pogledu postizanja ciljeva pravnog lica. Vjerovatnoća postizanja postavljenih ciljeva pravnog lica zavisi od ograničenja sadržanih u svim sistemima interne kontrole, a koja se ogledaju u sljedećem (COSO, 2013):

- ljudsko mišljenje ili odluka može biti pogrešna, a djelovanje nemarno ili nestručno,

- rukovodstvo ili zaposleni imaju mogućnost da pojedinačno ili kao više lica u dogovoru zaobiđu uspostavljene interne kontrole i time sistem kontrola učine nedjelotvornim,

- sistem internih kontrola se zasniva na ograničenim resursima, te se koristi od kontrola moraju suprotstaviti troškovima neophodnim za njihovo dostizanje.

Iz prethodno datih definicija, može se uočiti da značaj internih kontrola proističe iz njihove pomoći rukovodstvu da ostvari proklamovane poslovne ciljeve i vodi efikasnu politiku poslovanja što se najčešće ogleda kroz profitabilnost, 
sposobnost da se spriječi nastajanje gubitaka, pronevjera i zloupotreba, u sprovođenju budžeta i sl. Samim tim, nameće se zaključak da interne kontrole igraju značajnu, ako ne i odlučujuću ulogu u obezbjeđivanju realnog i pouzdanog finansijskog izvještavanja.

Najčešća podjela internih kontrola u preduzećima se ogleda u njihovom svrstavanju na administrativne i računovodstvene kontrole. Kada se posmatra funkcionisanje poslovnog sistema u neračunovodstvenim područjima tada govorimo o administrativnim kontrolama, dok su računovodstvene kontrole okrenute prevenciji nastanka nelegalnih, nepravilnih, neprihvatljivih i nemoralnih postupaka koji bi ugrozili imovinu, kapital i imidž preduzeća .

Prema Sawyer et al. (2003) svrha uspostavljanja internih kontrola se ogleda u njihovoj pomoći rukovodećem kadru u ostvarivanju proklamovanih ciljeva preduzeća koji se postižu kroz pružanje relevantnih, pouzdanih i vjerodostojnih finansijskih i poslovnih informacija; korišćenje resursa organizacije na efektivan i efikasan način; brigu o sredstvima organizacije; poslovanje usaglašeno sa zakonskim propisima, etičkim i poslovnim normama i ugovorima; identifikaciju nivoa rizika kojem je izložena kompanija i korišćenje efikasnih strategija za njegovu kontrolu; kao i jasnim postavljanjem ciljeva i težnji za poslovanje ili programe.

U međunarodnoj praksi je razvijeno nekoliko modela interne kontrole. U Engleskoj i velikom dijelu Evropske zajednice je razvijena upotreba Turnbulovog okvira, Kanadski komitet ovlašćenih računovođa - CICA (Canadian Institute of Chartered Accountants) je izradio CoCo okvir, spomenućemo možda i najznačajniji COSO okvir, koji je postao svjetski priznat okvir za utvrđivanje i upoznavanje sistema internih kontrola. COSO okvir se sastoji od pet komponenti koje su međusobno povezane, a koje uključuju kontrolno okruženje, procjenu rizika, kontrolne aktivnosti, informacije, komunikacije i monitoring (nadgledanje) (Stanišić, 2014).

\section{ODGOVORNOST RUKOVODSTVA ZA INTERNE KONTROLE}

Manja preduzeća misle da su imuna na pronevjere i prevare od strane njihovih lojalnih i pouzdanih zaposlenika. Pa ipak, mnoga mala preduzeća su nerijetko bila pogođena prevarama i najčešće nisu sebi mogla priuštiti ni najmanje greške, što je dovodilo do njihove propasti. Takođe, treba uzeti u obzir da prevare koje čini rukovodstvo nije lako zaustaviti jer nepostoji potpuna kontrola njihovih akcija. Rukovodstvo nadgleda interne kontrole, i generalno može raditi šta hoće, uključujući i zaobilaženje kontrola, kad god ga one sprečavaju u ostvarivanju ciljeva. Korporativno upravljanje, u svom sadašnjem obliku, je neefikasno jer se bazira na klasičnoj ekonomskoj teoriji i agencijskoj teoriji, koja je anahronična i promoviše suparnički odnos između akcionara i uprave, ali ignoriše postojanje zaposlenih. Morao bi se razviti bolji si- stem korporativnog upravljanja. Trebalo bi razmotriti interne kontrole koje sprovode američke korporacije, i na koje se nezavisni revizor mora osloniti kada procjenjuje integritet i pouzdanost računovodstvenih evidencija i njima rezultirajućih finansijskih izvještaja, jer sila zakona može biti zastrašujuća, ali tek nakon što je šteta učinjena.

Uprava je odgovorna za održavanje sistema internih kontrola nad finansijskim izvještavanjem (Internal Controls over Financial Reporting - ICFR) koji omogućuje razumno uvjeravanje o pouzdanosti finansijskog izvještavanja i pripreme finansijskih izvještaja za svrhe izvan preduzeća u skladu s opšte prihvaćenim računovodstvenim načelima. Komisija za hartije od vrijednosti (Securities Exchange Commission - SEC) je 2003. godine usvojila pravila za interne kontrole nad finansijskim izvještavanjem radi implementiranja člana 404 Sarbanes-Oxley zakona, koji zahtijeva da menadžment vrši godišnju procjenu da li su interne kontrole efektivne u pružanju razumnog uvjeravanja o pouzdanosti finansijskih izvještaja, i da svoju ocjenu objavi investitorima. Interne kontrole nad finansijskim izvještavanjem (ICFR) ne mogu pružiti apsolutnu sigurnost zbog svojih inherentnih ograničenja. To je proces koji uključuje ljudsku marljivost i usklađenost i podliježe pogrešnim odlukama i greškama koje proizilaze iz ljudskih neuspjeha. Takođe, ICFR se može zaobići, ako su zaposleni u dosluhu ili nema odgovarajućeg stava rukovodstva. Zbog takvih ograničenja, ICFR ne može spriječiti ili otkriti sve pogrešno prikazane podatke, bilo nenamjerne greške ili prevare.

\section{INTERNA KONTROLA KAO PRVA LINIJA ODBRANE}

Razne profesije poput internih revizora, stručnjaka za upravljanje rizikom, stručnjaka za usaglašenost poslovanja, stručnjaka za internu kontrolu, istražioca prevara, kontrolora kvaliteta i dr. sve češće rade u timovima koordinirajući svoje aktivnosti kako bi pomogli svojim organizacijama u upravljanju rizikom. Vlastiti ugao posmatranja i specifične vještine koje svaki od njih posjeduje mogu biti dragocjene za organizaciju. Takođe, činjenica da su različite nadležnosti, po pitanju rizika i kontrole, podijeljene i dodijeljene različitim odjeljenjima i sektorima u organizaciji, zahtjeva da se one sprovode pažljivo i koordinisano, obezbjeđujući da proces upravljanja rizikom i kontrole funkcionišu na željeni način.

U cilju ostvarivanja jednostavne i efektivne komunikacije po pitanjima rizika i kontrole uvodi se tzv. model „tri linije odbrane" (IIA, 2013) koji pojašnjava ključne uloge i zadatke pojedinih grupa u organizaciji. Ovim modelom je kreiran nov pogled na poslovanje, koji podržava kontinuiranu uspješnu inicijativu za upravljanje rizikom, a može se prilagoditi svakoj kompaniji, bez obzira na njenu veličinu i složenost poslovanja. Uvođenjem modela "tri linije odbrane“ pitanja rizika i kontrole se mogu učiniti jasnijim te pomoći poboljšanju efek- 


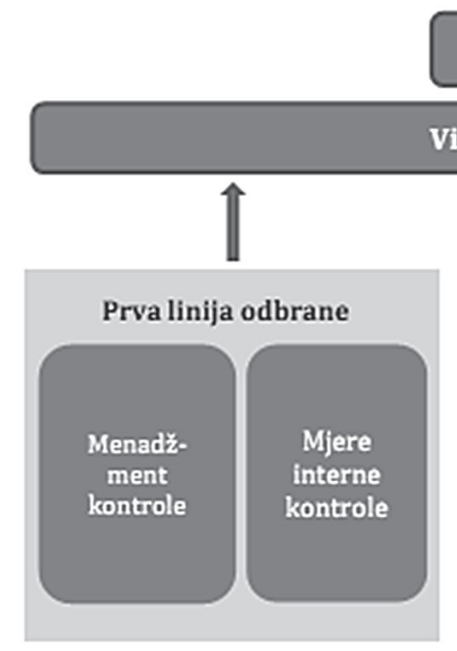

Upravni odbor/Odbor za reviziju

Više rukovodstvo
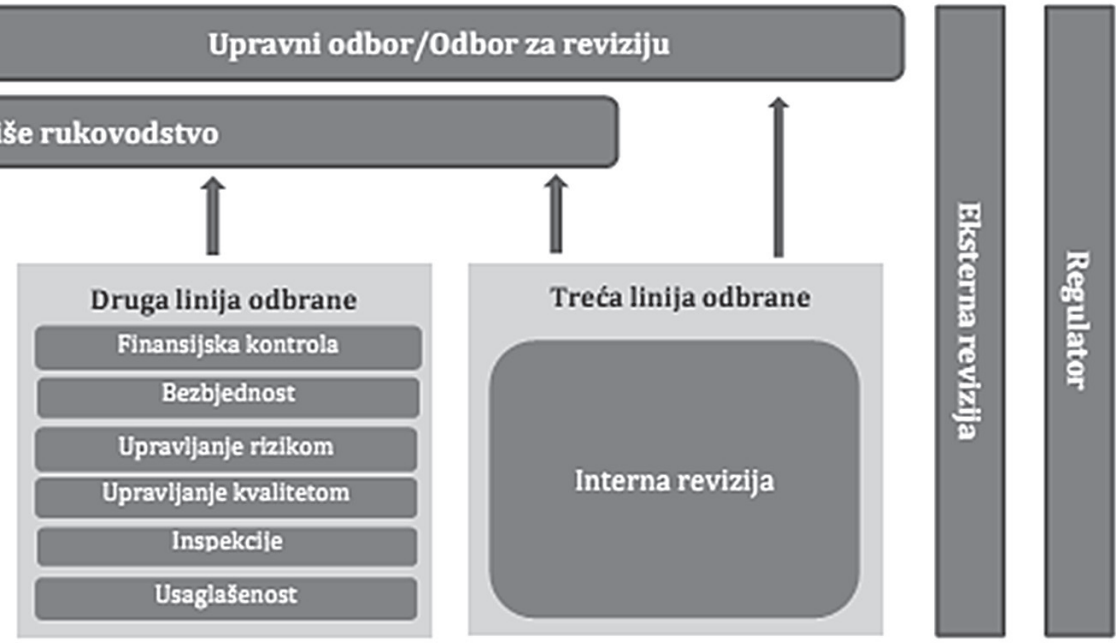

Slika 1. Model „Tri linije odbrane“ (prema IIA, 2013)

tivnosti sistema upravljanja rizikom čak i u organizacijama gdje okvir za upravljanje rizikom nije formalno uspostavljen (slika 1).

Prema modelu "tri linije odbrane“ (IIR, 2013) možemo razlikovati tri nivoa (ili linije) kroz koje se postiže efektivno upravljanje rizikom. Na prvom mjestu to su tzv. „vlasnici rizika" koji operativno sprovode upravljanje rizikom, na drugom nivou to su funkcije pomoću kojih se vrši nadgledanje rizika, i kao treći nivo imamo funkcije koje pružaju nezavisno uvjeravanje.

Kao prva linija odbrane, operativno rukovodstvo je „vlasnik“ rizika i direktno upravlja njime. Takođe, operativno rukovodstvo je odgovorno za preduzimanje korektivnih mjera za otklanjanje nedostataka u funkcionisanju procesa i kontrola. Kako bi interne kontrole i uspostavljeni postupci za kontrolu rizika funkcionisali efikasno i efektivno na dnevnoj osnovi, za njihovo uspostavljanje odgovorno je operativno rukovodstvo. Ono ima zadatak da identifikuje, procijeni, upravlja i ublaži rizik, kroz razvijanje i primjenu internih politika i procedura koje će obezbijediti konzistentnost aktivnosti iz svoje nadležnosti sa postavljenim zadacima i ciljevima. Sa druge strane, srednji nivo rukovodstva osmišljava i uvodi detaljne procedure za kontrolu i nadzor nad postupcima koje izvršavaju zaposleni. Iz tog razloga, adekvatne kontrole se uspostavljaju sa ciljem da nadgledaju usklađenost i obezbijede uvid u slabosti definisanih kontrola, neprihvatljivost procesa i nastanak neočekivanih događaja.

Možda bi se efektivno upravljanje rizikom u teoriji moglo obezbijediti i samo jednom linijom odbrane, no u realnom svijetu jedna linija u funkciji odbrane najčešće ne obezbjeđuje odgovarajuće rješenje. Mendžment treba da uspostavi različite funkcije za upravljanje rizikom kao i funkcije za usklađenost poslovanja, a sve u cilju nadgledanja fukcionisanja kontrola koje pripadaju prvoj liniji odbrane. Specifične funkcije će se razlikovati u zavisnosti od specifičnosti samih preduzeća i djelatnosti kojom se bave.
Kako bi se ostvarili vitalni ciljevi organizacije, $\mathrm{u}$ funkciju se stavlja druga linija odbrane koja upravi ne može pružiti apsolutno nezavisnu ocjenu po pitanjima upravljanja rizikom i internih kontrola. Interna revizija, kao treća linija odbrane, upravi i višem rukovodstvu obezbeđuje značajno uvjeravanje koje se bazira na visokom nivou nezavisnosti i objektivnosti koje ova funkcija ima u organizaciji, odnosno pruža uvjeravanje u efektivnost menadžmenta, upravljanja rizikom $\mathrm{i}$ internih kontrola, uključujući i način na koji prva i druga linija odbrane ostvaruju ciljeve upravljanja rizikom i funkcionisanja internih kontrola.

Svaki računovodstveni sistem treba da uspostavi i energično sprovodi efikasne interne kontrole - osnovne, dodatne oblike i procedure, i više od onoga što je obavezno da bi se poslovanje obavljalo neometano (Dummies). Ovi dodatni postupci služe da spriječe i otkriju greške (nenamjerne) i sve oblike (namjerne) neiskrenosti zaposlenih, klijenata, dobavljača, pa čak i samih menadžera. Nažalost, mnoga preduzeća nemaju dobre sisteme internih kontrola, ili neozbiljno sprovode svoje interne kontrole.

\section{REZULTATI ISTRAŽIVANJA}

Procesi internih kontrola se ogledaju u politikama, procedurama i aktivnostima koje čine dio okvira kontrole, a osmišljene su na način da obezbijede da rizici ne mogu izaći van okvira prihvatljivih granica utvrđenih u procesu upravljanja rizikom. Kada su kontrole definisane na način da sprečavaju pojavu neželjenih događaja tada govorimo o njihovoj preventivnoj funkciji. Pored preventivne, kontrole mogu biti u funkciji detekcije kada za cilj imaju otkrivanje i ispravljanje nepoželjnih događaja koji su već nastali, ili imati usmjeravajuću funkciju čiji je zadatak izazivanje ili podsticanje poželjnih događaja. Ukoliko je rukovodstvo planiralo i osmislilo interne kontrole na način da u razumnoj mjeri obezbjeđuju 
uvjeravanje da će se rizicima organizacije upravljati efektivno, te da će ciljevi organizacije biti ostvareni efikasno i ekonomično tada se smatra da su uspostavljene adekvatne kontrole.

U nastavku rada ćemo prikazati rezultate sprovedenog empirijskog istraživanja o efektivnosti menadžmenta u implementaciji mehanizama interne kontrole na uzorku od 150 preduzeća iz Bosne i Hercegovine. Anketa je bila upućena rukovodiocima finansijsko-računovodstvenog sektora, odnosno rukovodiocima poslovnog subjekta.

Istraživanje efektivnosti menadžmenta u implementaciji mehanizama interne kontrole u cilju prevencije prevara u finansijskim izvještajima na području $\mathrm{BiH}$ je sprovedeno sa ciljem da se utvdi postojeće stanje i prisutnost interne kontrole u preduzećima u $\mathrm{BiH}$, te stepen njihove efikasnosti. Nadamo se da će rezultati istraživanja koristiti praktičnim potrebama organizacija u Bosni i Hercegovini i regionu te ukazati na neophodnost djelovanja u pravcu otkrivanja i korišćenja mjera prevencije prevara u finansijskom izvještavanju u cilju povećanja kredibiliteta finansijskih izvještaja uopšte.

Anketiranje je sprovedeno u periodu od kraja septembra 2014. do polovine marta 2015. godine. Anketni upitnici su sadržali pitanja zatvorenog tipa, pri čemu je ponuđeno više odgovora. Popunjene anketne upitnike je vratilo ukupno 108 poslovnih subjekata, odnosno $72 \%$. Prema sjedištu, 73\% odnosno 79 anketiranih preduzeća je registrovano u Republici Srpskoj, 21\% (23 preduzeća) u Federaciji BiH, a preostalih 6\% (6 preduzeća) potiče iz Brčko Distrikta. Prema pravnom obliku, najveći broj anketiranih preduzeća čine društva $s$ ograničenom odgovornošću (72\%) i društva privatnog oblika svojine (75\%).

U anketiranom uzorku najzastupljenija su preduzeća iz oblasti trgovine sa $27 \%$ i prerađivačke industrije sa $22 \%$ preduzeća, za kojima, kao značajnije, slijede oblast građevinarstva (11\%), ostale javne i komunalne djelatnosti (9\%), te proizvodnja i snabdijevanje električnom energijom (6\%) i poljoprivreda, lov i šumarstvo sa $5 \%$. Za potrebe analize prikupljenih podataka, izvršena je klasifikacija anketiranih preduzeća na mala, srednja i velika uzimajući u obzir prosječan broj zaposlenih. ${ }^{1}$ Smatramo da broj zaposlenih ima značajniji uticaj na definisanje i funkcionisanje sistema interne kontrole od ostalih zakonom propisanih elemenata klasifikacije preduzeća po veličini. Uzimajući u obzir prethodno rečeno, u anketi je učestvovalo 71 malo preduzeće (do 50 zaposlenih), 24 srednja preduzeća (51-250 zaposlenih) i 13 velikih preduzeća (preko 251 zaposleni).

Analizirajući odgovore anketiranih preduzeća na pitanje da li imaju definisan i uspostavljen sistem interne kontrole,

1 Za potrebe istraživanja korišćena je klasifikacija propisana Zakonom o računovodstvu i reviziji RS (Sl. glasnik RS, br. 36/09) koji je bio u primjeni $\mathrm{u}$ periodu vršenja ankete, a koji propisuje da se pravna lica razvrstavaju na mala, srednja i velika u zavisnosti od prosječnog broja zaposlenih, ukupnog godišnjeg prihoda i vrijednosti imovine utvrđene na dan sastavljanja finansijskih izvještaja u poslovnoj godini, za šta je potrebno da preduzeće ispuni minimalno dva od tri postavljena uslova za klasifikaciju veličine. došli smo do rezultata da tek $61 \%$ preduzeća, odnosno 66 preduzeća ima implementiran sistem interne kontrole (grafikon 1).

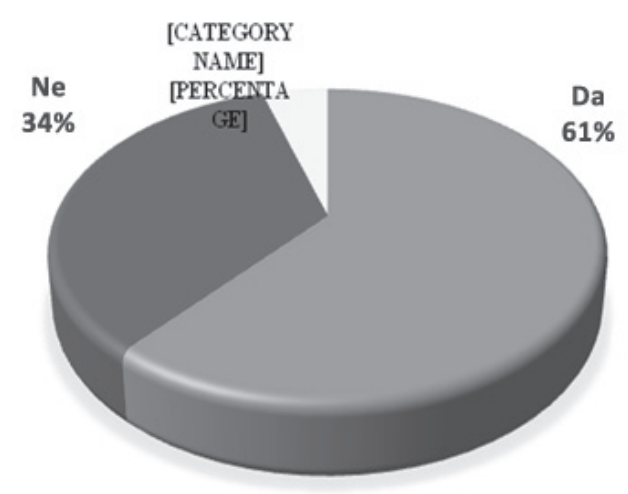

Grafikon 1. Stepen implementacije internih kontrola anketiranih preduzeća

Daljom analizom (grafikon 2 i 3), vidimo da je prema pravnom obliku preduzeća stepen implementacije internih kontrola sljedeći: interne kontrole su implementirane kod $80 \%$ akcionarskih društava, 55\% društava s ograničenom odgovornošću, 60\% anketiranih javnih preduzeća, kao i u 73\% anketiranih ustanova. Imajući u vidu da je postojanje službe interne revizije kao višeg nivoa internog nadzora zakonska obaveza akcionarskog društva i javnih preduzeća, interna revizija bi trebalo da nadgleda funkcionisanje sistema interne kontrole. Na osnovu navedenog, možemo zaključiti da stepen implementacije nije na zadovoljavajućem nivou, naročito kada su u pitanju javna preduzeća gdje postoji i značajan uticaj države.

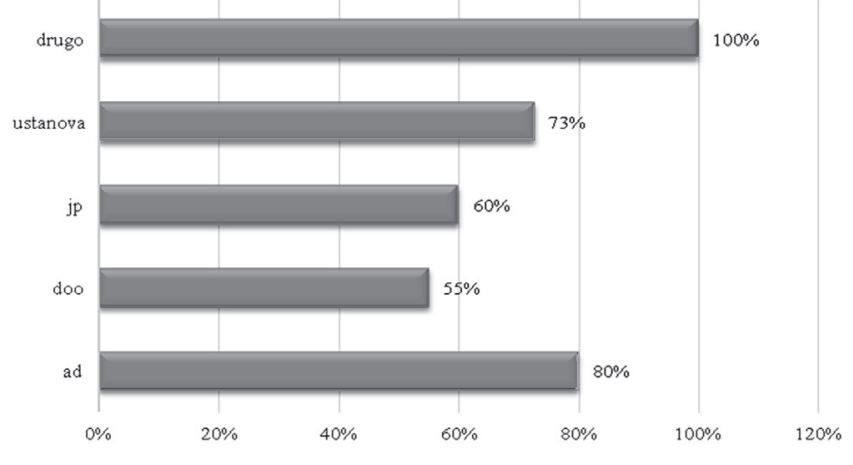

Grafikon 2. Implementirane IK prema pravnom obliku preduzeća

Gledano s aspekta veličine preduzeća, vidimo da je sistem interne kontrole implementiran u čak $85 \%$ anketiranih preduzeća koja zapošljavaju preko 251 radnika, što je za očekivati. Tek 55\% preduzeća sa do 50 zaposlenih ima uspostavljene interne kontrole, i $67 \%$ preduzeća sa 51 do 250 zaposlenih. 


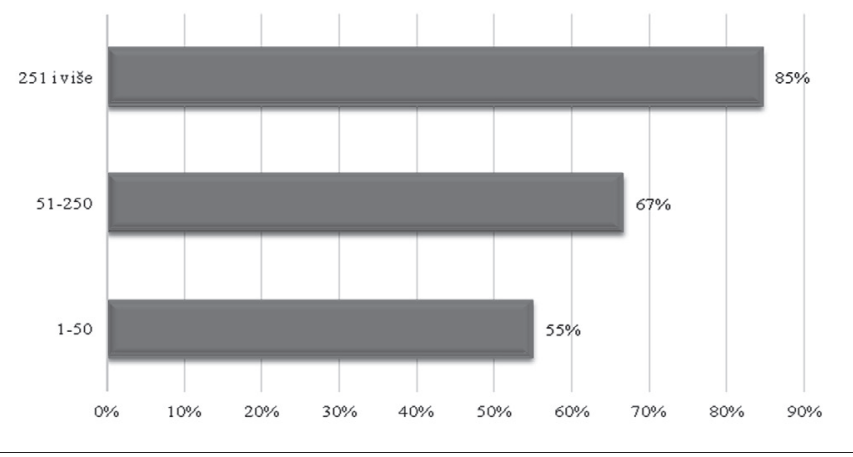

Grafikon 3. Implementirane IK prema veličini preduzeća

Na pitanje: Kako biste ocijenili efikasnost sistema interne kontrole u vašem preduzeću na skali od 1 do 5?, 23 subjekta su dala ocjenu 3, njih 26 je ocijenilo četvorkom, a 14 preduzeća ocjenom 5. Uzimajući u obzir sveukupne ocjene, prosječna ocjena efikasnosti sistema internih kontrola u privredi BiH bi iznosila 3,74 .

U nastavku smo analizirali prosječnu ocjenu efikasnosti sistema internih kontrola prema pravnoj formi što smo prikazali na grafikonu 4. Iako društava s ograničenom odgovornošću imaju najniži stepen implementacije, tamo gdje su uspostavljene, interne kontrole su visoko ocjenjivane te je najviša prosječna ocjena 3,84 . Zatim slijede ustanove s prosjekom 3,75, akcionarska društva koja u najvećoj mjeri imaju uspostavljene interne kontrole s prosječnom ocjenom 3,5 dok su najlošije ocijenjene interne kontrole u javnim preduzećima s prosjekom 2,67.

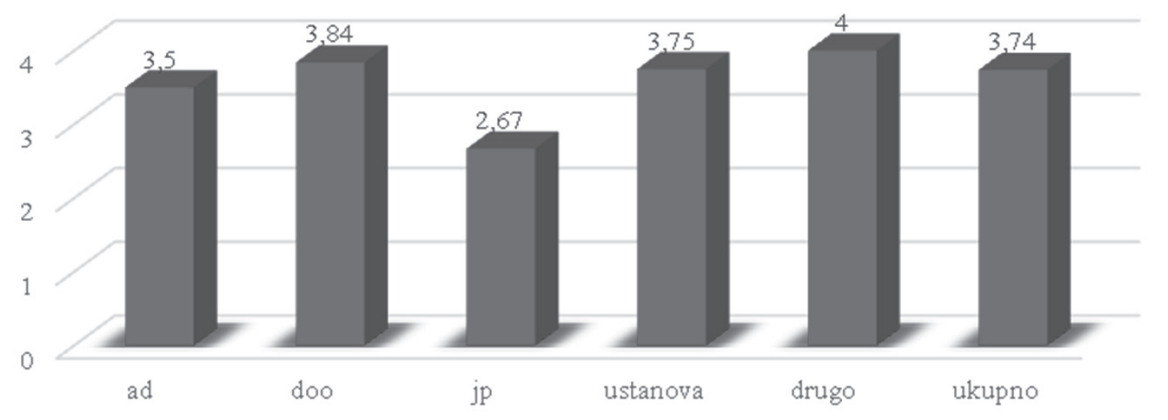

Grafikon 4. Prosječna ocjena efikasnosti IK posmatrano po pravnom obliku preduzeća

\section{ZAKLJUČAK}

Informacije koje pružaju finansijski izvještaji moraju biti jasne, relevantne, pouzdane i uporedive jer investitori i povjerioci donose odluke na bazi prezentovanih finansijskih izvještaja. Ukoliko finansijski izveštaji ne predstavljaju realnu sliku performansi preduzeća, štete do kojih dolazi se ne ogledaju samo u finansijskim gubicima zbog loše donijetih odluka već bi ovakva situacija, ako potraje, mogla dovesti do potpunog gubitka povjerenja korisnika, investitora i povjerilaca u finansijske izvještaje. Pored globalizacije, koja je zahvatila privredu u cjelini, kao bitan faktor koji je dodatno pojačao značaj zdravog finansijskog izvještavanja ističe se nastanak svjetskog, jedinstvenog finansijskog tržišta. U cilju ostvarivanja jednostavne i efektivne komunikacije po pitanjima rizika i kontrole uvodi se tzv. model „tri linije odbrane“ koji pojašnjava ključne uloge i zadatke pojedinih grupa u organizaciji. Ovim modelom je kreiran nov pogled na poslovanje, koji podržava kontinuiranu uspješnu inicijativu za upravljanje rizikom, a može se prilagoditi svakoj kompaniji bez obzira na njenu veličinu i složenost poslovanja.

U cilju postizanja kvalitetnog korporativnog upravljanja, a samim tim i upravljanja rizikom kompanije, neophodno je dobro razumijevanje sistema internih kontrola i načina na koji on funkcioniše u praksi. S obzirom na to da od sposobnosti organizacije da spozna rizike koji utiču ili bi mogli uticati na njeno poslovanje zavisi kvalitet korporativnog upravljanja, može se zaključiti da način upravljanja rizicima zavisi od učinkovitosti sistema internih kontrola.

Prema rezultatima sprovedenog istraživanja u $\mathrm{BiH}$, interne kontrole su uspostavljene tek kod $61 \%$ anketiranih preduzeća, i to u najvećoj mjeri kod anketiranih akcionarskih društava $80 \%$, a najmanje kod društava s ograničenom odgovornošću, svega 55\%. Uzimajući u obzir da je postojanje službe interne revizije zakonska obaveza akcionarskog društva, kao i javnog preduzeća, i da zbog toga interna revizija treba da nadgleda i funkcionisanje sistema interne kontrole, možemo zaključiti da stepen implementacije sistema internih kontrola nije na zadovoljavajućem nivou. To je naročito vidljivo kod javnih preduzeća gdje postoji i značajan uticaj države, a interne kontrole su najlošije ocijenjene s prosjekom 2,67, u odnosu na prosjek društava s ograničenom odgovornošću koji iznosi 3,84 , odnosno prosjek svih anketiranih koji iznosi 3,74.

Neophodno je shvatiti da interne kontrole imaju značajnu ulogu u obezbjeđivanju realnijeg i pouzdanijeg finansijskog izvještavanja. Njihovim uspostavljanjem i organizacijom, u preduzeću se želi postići realizacija mnogobrojnih ciljeva koji bi se uopšteno mogli svesti na obezbjeđenje uspješnog odvijanja poslovnih procesa, što vodi ostvarivanju utvrđenih ciljeva poslovanja.

\section{LITERATURA}

COSO. (1992). Internal Control - Integrated Framework. Retrieved Jun 30, 2016, from http://www.coso.org/documents/internal\%20control-integrated\%20framework.pdf 
COSO. (2013). Internal Control - Integrated Framework Executive Summary. Retrieved August 2, 2016, from http://www. coso.org/documents/990025P_Executive_Summary_final_may20_e.pdf

Dummies a Wiley Brand (2016). Why Accounting Systems Need Strong Internal Controls. Retrieved March 16, 2016, from http://www.dummies.com/business/operations-management/why-accounting-systems-need-strong-internalcontrols/

Durant, A. (2004). Fraud Preventions: The Latest Techniques Developing a Strategy to Fight Fraud. 15th Annual Fraud Conference, Las Vegas, NV. Retrieved Jun 27, 2016, from www.acfe.com

IIA Position Paper. (2013). The Three Lines of Defense in Effective Risk Management and Control. Retrieved Jun 16, 2016, from https://na.theiia.org/standards-guidance/Public\%20 Documents/PP\%20The\%20Three\%20Lines\%20of\%20Defense $\% 20$ in $\% 20$ Effective $\% 20$ Risk\%20Management $\% 20$ and\%20Control.pdf,

Ipsos MORI. (2001). British Job Applicants Are Lying On Their CVs. Retrieved July 25, 2016, from https://www.ipsos-mori. com/researchpublications/researcharchive/1189/BritishJob-Applicants-Are-Lying-On-Their-CVs.aspx

OECD. (2004). Principikorporativnogupravljanja. Retrieved Jun 30, 2016, from http://www.oecd.org/daf/ca/corporategovernanceprinciples/34625094.pdf
Savez računovođa, revizora i finansijskih radnika Federacije BiH. (2013). Međunarodni revizijski standard 315. SRRF $\mathrm{BiH}$. Retrieved July 2, 2016, from http://www.srr-fbih.org/ pdf/2013/02/Medjunarodni_revizijski_standardi-1.pdf

Sawyer, L. B., Dittenhofer, M. A., \& Scheiner, J. H. (2003). Sawyer's Internal Auditing: The Practice of Modern Internal Auditing. Altamonte Springs, FL: The Institute of Internal Auditors.

Securities and Exchange Commission. (2003). Final Rule: Management's Report on Internal Control over Financial Reporting and Certification of Disclosure in Exchange Act Periodic Reports. Retrieved July 25, 2016, from https://www. sec.gov/rules/final/33-8238.htm

Službeni glasnik Republike Srbije. (2009). Zakon o računovodstvu i reviziji RS. Sl. glasnik RS 36/09.

SRRS. (2002). Međunarodni standardi revizije. Beograd: Savez računovođa i revizora Srbije.

Stanišić, M. (2014). Interna kontrola i revizija. Beograd: Univerzitet Singidunum.

Udruženje internih revizora Srbije. (2013). Stanovište Instituta internih revizora (IIA): Tri linije odbrane za efektivni proces upravljanja rizikom i sistem interne kontrole. Retrieved July 20, 2016, from https://na.theiia.org/standards-guidance/ Public\%20Documents/PP\%20The\%20Three\%20Lines\%20 of\%20Defense $\% 20$ in\%20Effective\%20Risk\%20Management\%20and\%20Control\%20Serbian.pdf

\section{INTERNAL CONTROLAS A MEASURE OF FRAUD PREVENTION IN FINANCIAL REPORTING}

\section{Abstract:}

In order to achieve quality corporative governance and thus the governance of risk management, it is essential to have a profound understanding of internal control systems and how they actually operate in practice. The reason for this lies in the fact that how risk is managed depends on the performance of internal control systems, i.e. the quality of corporate governance depends on the ability of an organization to recognize the risks which affect or could affect its business.

Internal accounting control is a complex system of financial controls which are, among others, above all formal and substantive and aimed at providing reasonable assurance of the efficiency and effectiveness of operations, of their compliance with the laws and regulations, protecting assets from unauthorized use or disposition, as well as maintaining proper and accurate bookkeeping records which result in reliable financial information used for providing business information and decision making. In order to establish efficient and effective risk management in a company, risk and control responsibilities are divided and assigned to different departments and sectors of the company, while their careful and coordinated implementation ensures that risk management process and controls operate in a desired manner. In this paper we will take a closer look at internal controls as one of the most important assets of a company, the so-called first line of defense against fraudulent activities in financial reporting, as well as the degree and efficiency of their implementation on the example of the economy of Bosnia and Herzegovina.

\section{Keywords:}

internal controls, fraud prevention, risk management. 